\title{
Immunohistochemical studies of intrahepatic tumour necrosis factor $\alpha$ in chronic liver disease
} K Yoshioka, S Kakumu, M Arao, Y Tsutsumi, M Inoue, T Wakita, T Ishikawa,
M Mizokami

\begin{abstract}
To determine the intrahepatic production of tumour necrosis factor $\alpha$ (TNF $\alpha$ ) in chronic liver disease three monoclonal antibodies were used against TNF $\alpha$ in immunohistochemical studies of liver tissue sections from patients with chronic liver disease. All three monoclonal antibodies stained infiltrating mononuclear cells. Monoclonal antibody II 7C2 also stained the cytoplasm or nucleus, or both, of a varied number of hepatocytes from nine patients with chronic hepatitis $B$ virus infection, suggesting that the antigenic epitope related to hepatitis $B$ core antigen (HBcAg) crossreacted with IIC2. The other two monoclonal antibodies, III2F3 and IV3E5, stained significantly larger numbers of mononuclear cells in cases of chronic active hepatitis $B$ than in chronic persistent hepatitis $B$, or hepatitis $B$ related liver cirrhosis. III 2F3 stained significantly larger numbers of mononuclear cells in non$A$, non-B chronic active hepatitis than in chronic persistent hepatitis $B$ or hepatitis $B$ related liver cirrhosis.

These results indicate that TNF $\alpha$ is produced and secreted by infiltrating monoclear cells in focal inflammatory areas of the liver, and suggest that TNF $\alpha$ may have a role in the inflammatory activity of chronic liver disease.
\end{abstract}

Tumour necrosis factor (TNF) is found in the sera of mice injected with Bacillus CalmetteGúerin (BCG) and lipopolysaccharide (LPS). It causes in vivo necrosis of certain transplanted tumours in mice. ${ }^{1}$ In addition to its antitumour activity, TNF has multiple inflammatory and immunoregulatory properties, including induction of release of IL-1 by monocytes and endothelial cells, ${ }^{23}$ changes in antigenic expression ${ }^{4}$ and direct toxicity to normal cells, ${ }^{5}$ activation of natural killer cells, ${ }^{6}$ stimulation of $\mathrm{T}$ and $\mathrm{B}$ lymphocytes, ${ }^{78}$ and enhancement of production of interferon $\gamma .{ }^{9}$

A host of immunological abnormalities have been documented in chronic liver disease, for example, decreased production of interferons $^{1011}$ and interleukin 2 (IL-2), and decrease of $\mathrm{T}$ lymphocyte response to IL-2. ${ }^{12}$ Factors determining the outcome of chronic liver disease are not fully understood, but clearly, immunological responses of the host are important determinants. ${ }^{13} 14$

In a previous study we showed that TNF $\alpha$ production by peripheral blood mononuclear cells is increased in chronic liver disease and that this increase can be correlated with the activity of hepatitis. ${ }^{15}$ The present study was undertaken to determine whether the intrahepatic production of TNF $\alpha$ is increased in hepatitis B infection. We stained for TNF $\alpha$ in liver tissue sections from patients with chronic liver disease using immunohistochemical techniques with three monoclonal antibodies against TNF $\alpha$.

\section{Methods}

Studies were undertaken on 24 patients with chronic hepatitis $B$ virus infection and seven patients with chronic non-A, non-B hepatitis. Details of the patients studied are summarised in table 1. Patients with liver disease were diagnosed on the basis of appropriate serological, virological, biochemical and histological criteria. ${ }^{16} \mathrm{HBsAg}$, anti-HBs, anti-HBc, $\mathrm{HBeAg}$ and anti-HBe were determined with commercially available radioimmunoassay kits (Abbott Laboratories, North Chicago, USA). Hepatitis B infection was diagnosed if HBsAg was serologically positive. Non-A, non-B hepatitis was diagnosed after infection with known viruses including type $A$ and type $B$ hepatitis virus, cytomegalovirus, and EpsteinBarr virus had been excluded. Patients classified as having non-A, non-B hepatitis did not have autoimmune hepatitis, drug induced hepatitis, or alcoholic liver disease.

Three monoclonal antibodies against human TNF $\alpha$, II 7C2, III 2F3, and IV 3E5, were gifts from Asahi Chemical Industry (Japan). ${ }^{17}$

Liver biopsy samples obtained from all patients were divided into two parts. One part was fixed in $10 \%$ formalin for routine histological staining. The other portion was fixed in periodate-lysine-paraformaldehyde solution for immunoperoxidase staining. ${ }^{18}$ Cryostat sections $(6 \mu \mathrm{m}$ thick) were pretreated with hydrogen peroxide and methanol to inactivate endogenous tissue peroxidase. The sections were incubated with monoclonal antibodies against TNF $\alpha$ at $4^{\circ} \mathrm{C}$ overnight. The concentrations of monoclonal antibodies used were 20 $\mu \mathrm{g} / \mathrm{ml}$ for II $7 \mathrm{C} 2,80 \mu \mathrm{g} / \mathrm{ml}$ for III $2 \mathrm{~F} 3$, and 80 $\mu \mathrm{g} / \mathrm{ml}$ for IV $3 E 5$. After washing with $0.15 \mathrm{M}$ phosphate buffered saline (PBS), $\mathrm{pH} 7 \cdot 4$, the sections were incubated with horseradishperoxidase-conjugated anti-mouse IgG (Tago, Inc, Burmingame, California) at $4^{\circ} \mathrm{C}$ overnight. After washing in PBS they were then treated with diaminobenzidine solution containing hydrogen peroxide for 10 minutes, 
Table 1 Clinical details of patients studied

\begin{tabular}{|c|c|c|c|c|c|}
\hline Diagnosis (No of patients studied) & Sex & $\begin{array}{l}\text { Age } \\
\text { (years) } \\
\text { (normal range) }\end{array}$ & $\begin{array}{l}A L T \\
(I U / l 0-45)\end{array}$ & $\begin{array}{l}\gamma \text {-globulin } \\
(g / d l) \\
(0.76-1.69)\end{array}$ & $\begin{array}{l}H B e A g \\
(+I-)\end{array}$ \\
\hline $\begin{array}{l}\text { Chronic active hepatitis B (12) } \\
\text { Chronic persistent hepatitis B (6) } \\
\text { Hepatitis related liver cirrhosis (6) } \\
\text { Non-A, non-B chronic active hepatitis ( } 7 \text { ) }\end{array}$ & $\begin{array}{l}1 / 11 \\
2 / 4 \\
0 / 6 \\
1 / 6\end{array}$ & $\begin{array}{l}30 \cdot 2(12 \cdot 0) \\
30 \cdot 5(14 \cdot 1) \\
38 \cdot 6(6 \cdot 7) \\
49 \cdot 3(10 \cdot 4)\end{array}$ & $\begin{array}{c}166 \cdot 1(109 \cdot 8) \\
76 \cdot 3(42 \cdot 6) \\
106 \cdot 2(113 \cdot 8) \\
301 \cdot 4(116 \cdot 0)\end{array}$ & $\begin{array}{l}1.3(0 \cdot 3) \\
1.3(0 \cdot 3) \\
1.5(0.5) \\
1.3(0.4)\end{array}$ & $\begin{array}{l}7 / 5 \\
4 / 2 \\
1 / 5\end{array}$ \\
\hline
\end{tabular}

All laboratory data are expressed as mean (SD).

counterstained with methyl green, dehydrated, and mounted. The number of cells positive for TNF $\alpha$ was expressed as number of cells positive for TNF $\alpha / \mathrm{mm}^{2}$.

II7C2 stained hepatocytes of several patients with chronic hepatitis $B$ infection, but not the hepatocytes of patients with chronic non-A, non-B hepatitis infection. To assess the relation between positive staining of hepatocytes by II 7C2 and presence of hepatitis $B$ virus related antigens in hepatocytes, therefore, tissue sections were also stained by mouse monoclonal antibody to HBsAg (MBL Inc, Japan) and mouse monoclonal antibody to $\mathrm{HBcAg}$, which was kindly provided by Dr Mitsunobu Imai of Jichi Medical School (Japan). ${ }^{19}$

To verify the specificity of the reaction, the reagent tested as a control first antibody was normal mouse serum.

The Wilcoxon and $\chi^{2}$ tests and linear regression analysis were used to analyse the data.

\section{Results}

The major cell type stained by the three monoclonal antibodies against TNF $\alpha$ in liver

Figure 1 II $7 C 2$ stained five mononuclear cells in portal area of a patient with chronic active hepatitis $B$ (arrows).

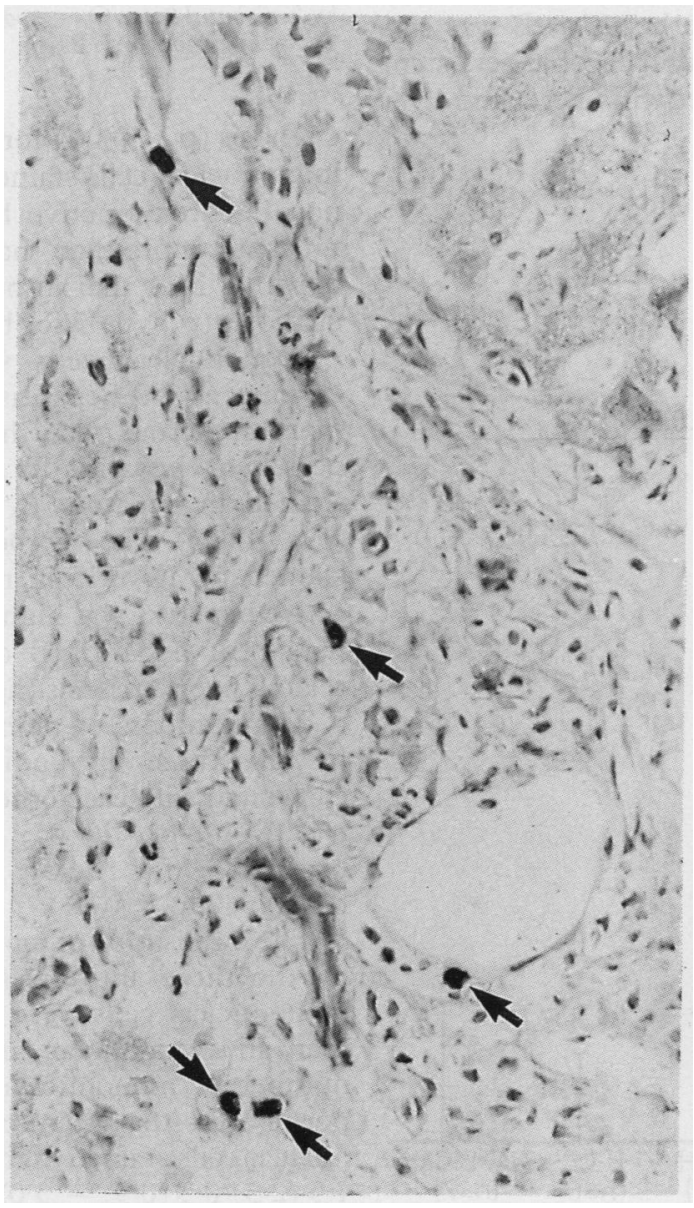

tissue was the infiltrating mononuclear cell (figs 1 and 2). The positive material appeared diffusely in the cytoplasm. Kupffer cells, endothelial cells, polymorphs, fibroblasts, and bile duct cells were not stained. In addition to mononuclear cells, II 7C2 stained cytoplasm or nucleus, or both, of a varied number of hepatocytes in nine patients, while the other two monoclonal antibodies, III $2 \mathrm{~F} 3$ and IV 3E5, did not stain hepatocytes (fig 3). As all nine patients whose hepatocytes were stained by II 7C2 were also positive for serum $\mathrm{HBsAg}$, and eight of the nine were positive for serum $\mathrm{HBeAg}$, we assessed the relation between

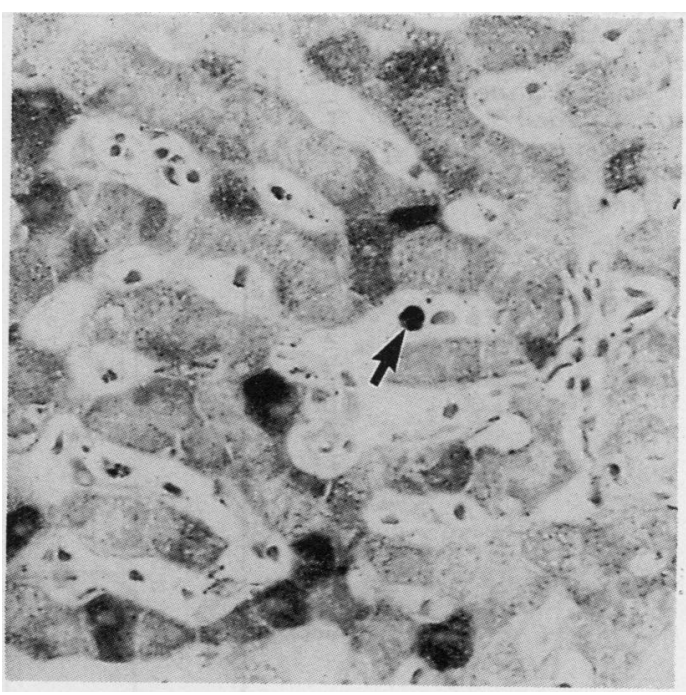

Figure 3 II 7C2 stained the cytoplasm of hepatocytes and a mononuclear cell (arrow) of a patient with chronic active hepatitis $B$. 
Table 2 Relation between positive staining of hepatocytes by II 7C2 and presence of hepatitis $B$ related antigens in serum and in hepatocytes of 24 patients with chronic hepatitis $B$ infection

\begin{tabular}{|c|c|c|c|c|}
\hline II $7 C 2$ & $\begin{array}{l}\text { No of } \\
\text { patients }\end{array}$ & $\begin{array}{l}\text { Serum } \\
\text { HBeAg } \\
+1-\end{array}$ & $\begin{array}{l}\text { Hepatocytes } \\
\text { HBsAg } \\
+1-\end{array}$ & $\begin{array}{l}H B c A g \dagger \\
+l-\end{array}$ \\
\hline $\begin{array}{l}\text { Positive staining of hepatocytes } \\
\text { Negative staining of hepatocytes }\end{array}$ & $\begin{array}{r}9 \\
15\end{array}$ & $\begin{array}{l}8 / 1 \\
4 / 11\end{array}$ & $\begin{array}{l}8 / 1 \\
6 / 9\end{array}$ & $\begin{array}{l}8 / 1 \\
3 / 12\end{array}$ \\
\hline
\end{tabular}

positive staining of hepatocytes by II7C2 and the presence of $\mathrm{HBsAg}$ or $\mathrm{HBcAg}$ in hepatocytes (table 2). Eight of the nine patients whose hepatocytes took up II7C2 had hepatocytes stained by monoclonal antibody against $\mathrm{HBcAg}$. Twelve of 15 patients whose hepatocytes were not stained by II 7C2 had no hepatocytes positive for $\mathrm{HBcAg}$. The number of patients with positive staining of hepatocytes by II7C2 and those positive by monoclonal antibody against $\mathrm{HBcAg}$ was significantly correlated $(p<0.005)$. The localisation of hepatocytes stained by II7C2 and the intracellular localisation of staining (cytoplasm or nucleus) were almost the same as those stained by monoclonal antibody against $\mathrm{HBcAg}$. Positive staining of hepatocytes by II 7C2 and presence of $\mathrm{HBsAg}$ in hepatocytes were not significantly correlated.

II7C2 stained significantly higher numbers of mononuclear cells in chronic active hepatitis $B$ than in non- $A$, non- $B$ chronic active hepatitis $(\mathrm{p}<0.05)$ (fig 4$)$.

The number of mononuclear cells stained by III2F3 in chronic active hepatitis B was significantly higher than that in chronic persistent hepatitis B, or that in hepatitis B related liver

Figure 4 Number of mononuclear cells stained by II 7C2 in patients with chronic active hepatitis $B$ (B-CAH), chronic persistent hepatitis $B(B$ $C P H)$, hepatitis $B$ related liver cirrhosis $(B-L C)$, and non- $A$, non- $B$ chronic active hepatitis (NANB$C A H)$. Mean ( $S D$ ) values of mononuclear cells stained are indicated by horizontal bars:

$\mathrm{O}=$ positive for $\mathrm{HBeAg} ; \mathrm{O}=$ negative for $\mathrm{HBeAg}$.

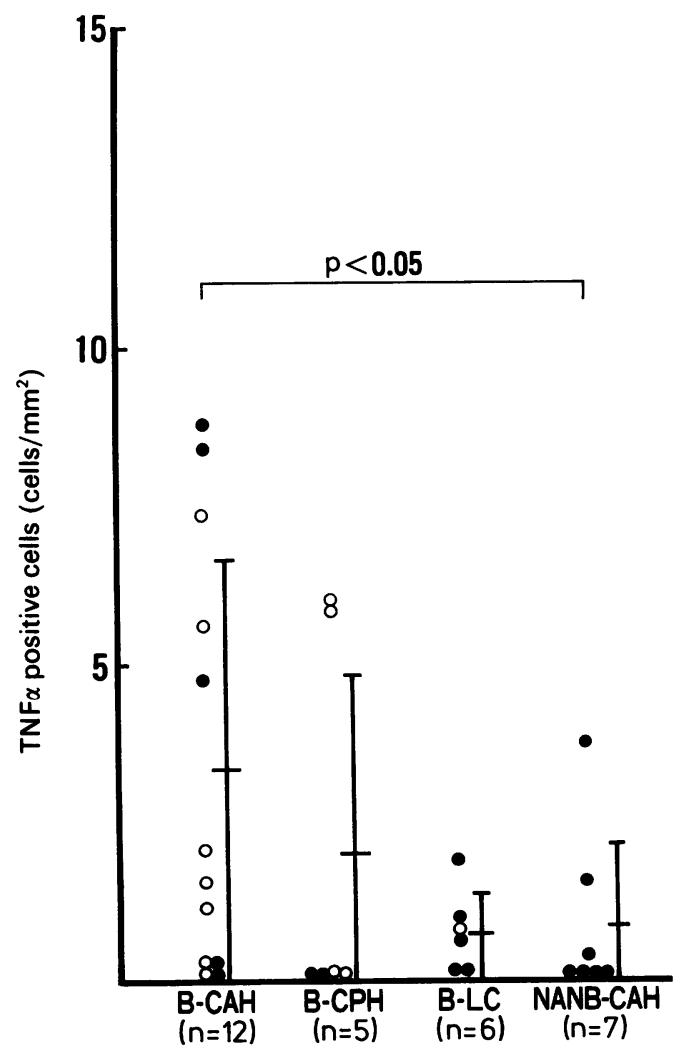

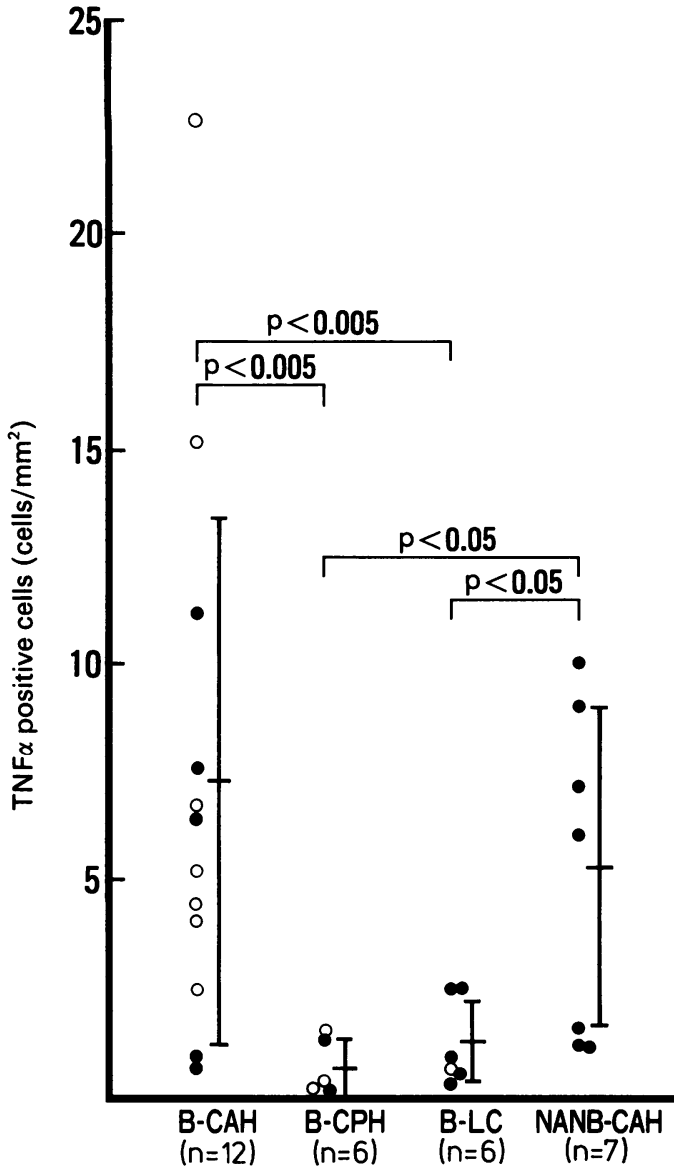

Figure 5 Number of mononuclear cells stained by III $2 F 3$ in patients with chronic active hepatitis $B$

$(B-C A H)$, chronic persistent hepatitis $B(B-C P H)$, hepatitis $B$ related liver cirrhosis ( $B-L C)$, and non- $A$, non- $B$ chronic active hepatitis (NANB-CAH). Mean $(S D)$ values of mononuclear cells stained are indicated by horizontal bars: $\bigcirc=$ positive for $\mathrm{HBeAg}$;

$=$ negative for $\mathrm{HBe} \mathrm{Ag}$.

cirrhosis ( $p<0.005$ for both). The number of mononuclear cells stained by III2F3 in non-A, non-B chronic active hepatitis was also significantly more than that in chronic persistent hepatitis B or that in hepatitis B related liver cirrhosis ( $p<0.05$ for both) (fig 5).

Mononuclear cells stained by IV3E5 in chronic active hepatitis B were significantly more numerous than those stained in chronic persistent hepatitis $B(p<0.01)$ or those stained in hepatitis B related liver cirrhosis $(p<0.005)$. The number of mononuclear cells stained by IV 3 E5 in non-A, non-B chronic active hepatitis was higher than that in chronic persistent hepatitis B or that in hepatitis B related liver cirrhosis (fig 6).

The numbers of mononuclear cells stained by the three antibodies were significantly correlated with each other (II 7C2 and III 2F3, $\mathrm{r}=0.540, \mathrm{p}<0.01 ;$ II $7 \mathrm{C} 2$ and IV 3E5, $r=0.573, p<0.001$; III $2 F 3$ and IV 3E5, $\mathrm{r}=0.547, \mathrm{p}<0.01$ )

The localisation of mononuclear cells stained by the three antibodies was assessed. More mononuclear cells were stained in portal areas than in intralobular areas (the mean (SD) number of mononuclear cells stained in the portal areas/the mean (SD) number of mononuclear cells stained in the intralobular areas = $1.5(2 \cdot 3) / 0.5(0.9)=3.03$ for II $7 \mathrm{C} 2,3.5(4.4) /$ 


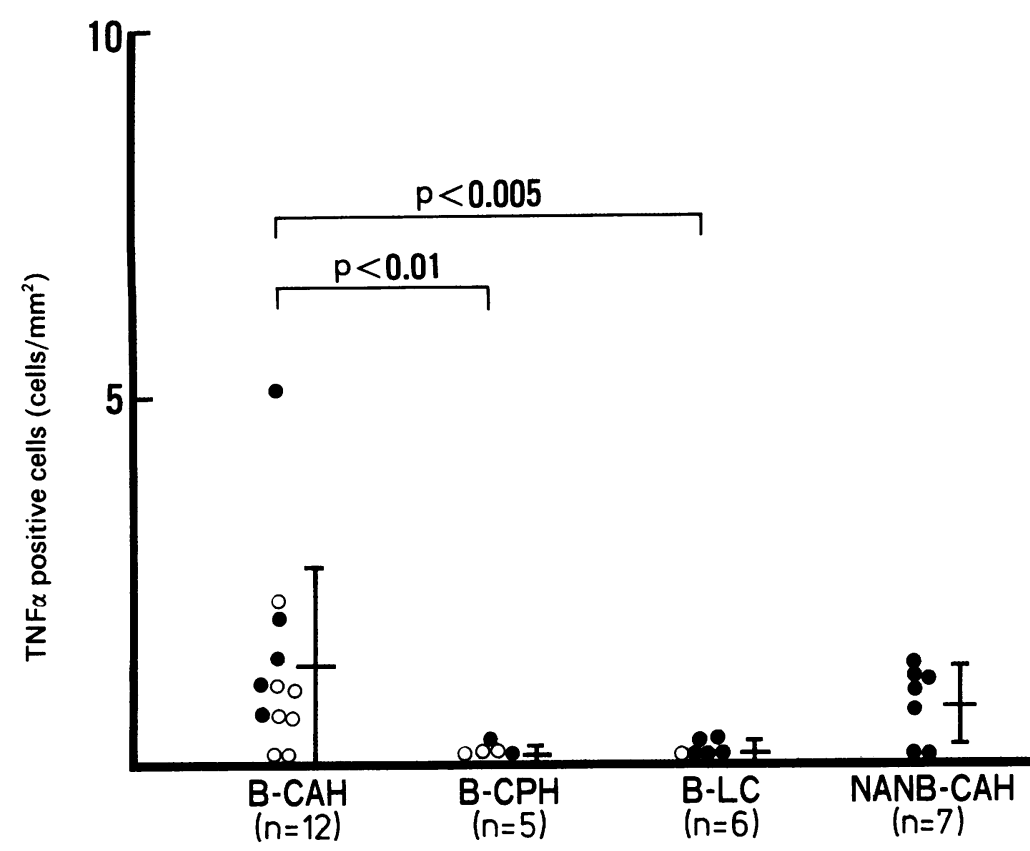

Figure 6 Number of mononuclear cells stained by IV $3 E 5$ in patients with chronic active hepatitis $B(B-C A H)$, chronic persistent hepatitis $B(B-C P H)$, hepatitis $B$ related liver cirrhosis ( $B-L C$ ), and non- $A$, non- $B$ chronic active hepatitis (NANB$C A H)$. Mean (SD) values of mononuclear cells stained are indicated by horizontal bars: $\bigcirc=$ positive for $\mathrm{HBeAg} ; \bigcirc=$ negative for $\mathrm{HBe} \mathrm{Ag}$.

$1 \cdot 0(1 \cdot 2)=3.32$ for III $2 \mathrm{~F} 3,0.5(1 \cdot 0) / 0 \cdot 2(0 \cdot 4)$ $=2.94$ for IV 3E5).

\section{Discussion}

This study has shown that the numbers of mononuclear cells stained by the three monoclonal antibodies were significantly correlated with each other, and the numbers of mononuclear cells stained by III2F3 in chronic active hepatitis $B$ or those in non- $A$, non-B chronic active hepatitis were significantly higher than those stained in chronic persistent hepatitis B or hepatitis B related liver cirrhosis, and the numbers of mononuclear cells stained by IV $3 E 5$ in chronic active hepatitis B were significantly more than those in chronic persistent hepatitis B or hepatitis B related liver cirrhosis. These results indicate that TNF $\alpha$ is produced by infiltrating mononuclear cells in chronic liver disease, and that the number of mononuclear cells producing TNF $\alpha$ in chronic active hepatitis is higher than that in chronic persistent hepatitis or liver cirrhosis. Our data are consistent with the results of our previous study which showed that TNF $\alpha$ production by peripheral blood mononuclear cells is increased in chronic liver disease, and that this increase is related to the activity of the hepatitis. ${ }^{15}$ It is likely that the TNF $\alpha$ secreted by mononuclear cells in focal inflammatory areas diffuse into surrounding areas, thereby modulating the inflammatory activity in chronic liver disease.

The number of mononuclear cells stained in the portal areas was about three times that stained in the intralobular areas. This ratio of the numbers of mononuclear cells stained for TNF $\alpha$ is probably proportional to that of all the infiltrating mononuclear cells in these areas.

Because monocytes are a predominant cellular source of TNF $\alpha$, the mononuclear cells stained by the three monoclonal antibodies may be monocytes. It has been reported, however, that $\mathrm{T}$ cells and natural killer cells also produce TNF $\alpha .{ }^{2021}$ The light microscopic observation of peroxidase staining is also insufficient to determine the cell type of the mononuclear cells. The mononuclear cells stained, therefore, may be activated lymphocytes as well as monocytes.

In a model of autoimmunity and vasculitis Magilavy and Rothstein recently showed that Kupffer cells isolated from MRL/lpr mice spontaneously produced high concentrations of TNF $\alpha$ in vitro. ${ }^{22}$ Kupffer cells were not stained by any of the three monoclonal antibodies against TNF $\alpha$ in our study. Kupffer cells may have produced very little or no TNF $\alpha$ in chronic liver disease in man. Another possibility is that Kupffer cells produced a TNF $\alpha$ that is antigenetically different from TNF $\alpha$ produced by mononuclear cells.

The patients with positive staining of hepatocytes by II7C2 and those with positive staining by monoclonal antibody against $\mathrm{HBcAg}$ were significantly correlated with each other. The localisation of hepatocytes stained by II7C2 and the intracellular localisation of staining (cytoplasm or nucleus) were almost the same as those stained by monoclonal antibody against $\mathrm{HBcAg} .{ }^{23}$ It is likely that the antigenic epitope related to $\mathrm{HBcAg}$ crossreacts with II7C2. P19, a polypeptide consisting of 183 amino acids, which is purified from recombinant $\mathrm{HBcAg},{ }^{19}$ reacted with $I I 7 \mathrm{C} 2$ but not with III2F3 nor IV 3E5 in enzyme linked immunosorbent assays (data not shown). II7C2 probably stained $\mathrm{HBcAg}$ related antigen in a similar manner to P19 in hepatocytes. It would be of interest to know the region of the TNF $\alpha$ molecule with which II7C2 interacts. As the three monoclonal antibodies abolish the bioactivity of TNF $\alpha$, it seems that they bind to the epitopes near the receptor binding sites of TNF $\alpha$. As a monoclonal antibody binds to an epitope consisting of only three to seven amino acid residues, it sometimes cross reacts with a different antigen with an epitope whose amino acid sequence is similar to the true epitope. We compared the amino acid sequence of TNF $\alpha$ and $\mathrm{HBcAg}$ by a homology matrix method. The sequence 140-145 Asp-Tyr-Leu-AspPhe-Ala of TNF $\alpha$ was found to be identical with the sequence 58-63 Asp-Leu-Leu-AspThr-Ala of HBcAg, except for two residues. The sequence $140-145$ of TNF $\alpha$ was also shown to be hydrophilic. Therefore, it may be that II7C2 reacts with the sequence $140-145$ of TNF $\alpha$ and crossreacts with the sequence 5863 of $\mathrm{HBcAg}$.

II7C2 stained a significantly larger number of mononuclear cells in chronic active hepatitis $B$ than in non- $A$, non-B chronic active hepatitis. We assume that II7C2 stained $\mathrm{HBcAg}$-related antigen, like P19 captured by mononuclear cells, besides staining for TNF $\alpha$ in chronic active hepatitis $B$. On the other hand, the number of mononuclear cells stained by III2F3 and IV3E5 did not significantly differ between chronic active hepatitis $B$ and non-A, non-B chronic active hepatitis. 
TNF $\alpha$ was originally described as causing necrosis of tumours in vivo and as killing tumour cells in vitro. ${ }^{1}$ TNF $\alpha$ also has a modulatory function of the immune system such as stimulation of neutrophils, ${ }^{24} \mathrm{~T}$ and $\mathrm{B}$ lymphocytes, ${ }^{89}$ enhancement of HLA expression on various cells, ${ }^{4}$ and induction of production of acute phase proteins. ${ }^{25}$ Recently, TNF $\alpha$ has been implicated in endotoxic shock. ${ }^{26}$ In chronic liver disease TNF $\alpha$ may stimulate the proliferation of $\mathrm{T}$ and $\mathrm{B}$ lymphocytes in local inflammatory areas and the production of various cytokines or immunoglobulins. Thus TNF $\alpha$ may have a critical role in maintaining or accelerating inflammatory activity in the liver. Creasey et al reported that TNF is cytotoxic to normal cells when they are exposed to actinomycin D. ${ }^{5}$ This suggests that TNF $\alpha$ may be directly cytotoxic to hepatocytes. The evidence for this point requires further clarification.

1 Carswell EA, Old LJ, Kassell RL, Green S, Fiore N, Williamson B. An endotoxin-induced serum factor that causes necrosis of tumors. Proc Natl Acad Sci USA 1975;72:3666-70.

2 Dinarello CA, Cannon JG, Wolff SM, et al. Tumor necrosis factor (cachectin) is an endogenous pyrogen and induces factor (cachectin) is an endogenous pyrogen and induces

production of interleukin 1. JExp Med 1986;163:1433-50.
Nawroth PP, Bank I, Handley D, Cassimeris J, Chess L, Stern D. Tumor necrosis factor/cachectin interacts with Stern $D$. Tumor necrosis factor/cachectin interacts with endothelial cell receptors to ind
$J E x p$ Med 1986;163:1363-75.

4 Collins T, Lapierre LA, Fiers W, Strominger JL, Pober J. Recombinant human tumor necrosis factor increases mRNA levels and surface expression of HLA-A, B antigens in vascular endothelial cells and dermal fibroblasts in vitro. Proc Natl Acad Sci USA 1986; 83:446-50.

5 Creasey AA, Doyle LV, Reynolds T, Jung T, Lin LS, Vitt CR. Biological effects of recombinant human tumor necrosis factor and its novel muteins on tumor and normal necrosis factor and its novel muteins on

6 $\emptyset$ stensen ME, Thiele DL, Lipsky PE. Tumor necrosis factor- $\alpha$ enhances cytolytic activity of human natural killer cells. J Immunol 1987;138:4185-91.

7 Yokota S, Geppert TD, Lipsky PE. Enhancement of antigen- and mitogen-induced human $T$ lymphocyte
proliferation by tumor necrosis factor- $\alpha$. J Immunol 1988;140:531-6.

8 Jelinek DF, Lipsky PE. Enhancement of human B cell proliferation and differentiation by tumor necrosis factor$\alpha$ and interleukin 1.J Immunol 1987;139:2970-6.

9 Scheurich P, Thoma B, Ücer U, Pfizenmaier K. Immuno- regulatory activity of recombinant human tumor necrosis factor (TNF)- $\alpha$ : induction of TNF receptors on human T cells and TNF- $\alpha$-mediated enhancement of T cell responses. J Immunol 1987;138:1786-90.

10 Kato Y, Nakagawa H, Kobayashi K, Hattori N, Hatano K. Interferon production by lymphocytes in $\mathrm{HBsAg}$-positive liver diseases. Hepatology 1982;2:789-90.

11 Fuji A, Kakumu S, Ohtani Y, Murase K, Hirofuji H, Tahara $H$. Interferon- $\gamma$ production by peripheral blood mononuclear cells of patients with chronic liver disease. Hepatology 1987;7:577-81.

12 Yoshioka K, Kakumu S, Murakami H, Fukui K. Interleukin-2 activity in chronic liver diseases: responses by $T$ cells in -2 activity in chronic liver diseases: responses by T cells Exp Immunol 1984;56:668-76.

13 Dudley FJ, Fox RA, Sherlock S. Cellular immunity and hepatitis-associated Australia antigen liver disease. Lancet 1972;i:723-6.

14 Eddleston ALWF, Williams R. Inadequate antibody response to $\mathrm{HbsAg}$ or suppressor $\mathrm{T}$-cell defect in development of active chronic hepatitis. Lancet 1974;ii:1543-5.

15 Yoshioka K, Kakumu S, Arao M, Tsutsumi Y, Inoue M. Tumor necrosis factor $\alpha$ production by peripheral blood mononuclear cells of patients with chronic liver disease. mononuclear cells of patients
Hepatology 1989;10:769-73.

16 Leevy CM, Popper H, Sherlock S. Diseases of the liver and biliary tract. In: Standardization of nomenclature, diagnostic criteria and diagnostic methodology. London: Castle House Publications, 1979

17 Yamazaki S, Onishi E, Enami K, et al. Proposal of standardized methods and reference for assaying recombinant tumor necrosis factor. Japan J Med Sci Biol 1986;39: 105-18.

18 McLean IW, Nakane PK. Periodate-lysine-paraformaldehyde fixative: a new fixative for immunoelectron microscopy. J Histochem Cytochem 1974;22:1077-83.

19 Takahashi K, Machida A, Funatsu G, et al Immunochemical structure of hepatitis Be antigen in the serum. $J$ Immunol 1983;130:2903-7.

20 Steffen M, Ottman OG, Moore MA. Simultaneous production of tumor necrosis factor- $\alpha$ and lymphotoxin by normal $\mathrm{T}$ cells after induction with IL-2 and anti-T3. $J$ Immunol 1988;140:2621-4.

21 Wright SC, Bonavida B. Studies on the mechanism of natural killer cell-mediated cytotoxicity. VII. Functional comparison of human natural killer cytotoxic factors with recombinant lymphotoxin and tumor necrosis factor. $J$ Immunol 1987;138:1791-8.

22 Magilavy DB, Rothstein JL. Spontaneous production of tumor necrosis factor $\alpha$ by Kupffer cells of MRL/lpr mice. tumor necrosis factor $\alpha$ by Ku

23 Kakumu S, Arao $M$, Yoshioka K, Tsutsumi Y, Inoue $M$. Distribution of $\mathrm{HBcAg}$ in hepatitis $\mathrm{B}$ detected by immunoperoxidase staining with three different preparations of anti-HBc antibodies. J Clin Pathol 1989;42:284-8.

24 Shalaby MR, Aggarwal BB, Rinderknecht E, Svedersky LP, Finkle BS, Palladino MA. Activation of human polymorphonuclear neutrophil functions by interferon- $\gamma$ and tumor necrosis factors. J Immunol 1985;135:2069-73.

25 Darlington GJ, Wilson DR, Lachman LB. Monocyteconditioned medium, interleukin-1 and tumor necrosis factor stimulate the acute phase response in human factor stimulate the acute phase response in hum
hepatoma cells in vitro. J Cell Biol 1986;103:787-93.

26 Beutler B, Milsark IW, Cerami A. Passive immunization against cachectin/tumor necrosis factor protects mice against cachectin/tumor necrosis factor protects mice
from lethal effect of endotoxin. Science 1985;229:869-71. 